\title{
ANGKA KEJADIAN DIARE PADA ANAK DENGAN LEUKEMIA LIMFOBLASTIK AKUT DI RSUP PROF. DR. R. D. KANDOU MANADO PERIODE TAHUN 2011-2015
}

\author{
Fatmawati Latamu \\ Jeanette I. Ch. Manoppo \\ Max F. J. Mantik \\ ${ }^{1}$ Kandidat Skripsi Fakultas Kedokteran Universitas Sam Ratulangi \\ ${ }^{2}$ Bagian Ilmu Kesehatan Anak Fakultas Kedokteran Universitas Sam Ratulangi \\ Email : fatma.latamu@gmail.com
}

\begin{abstract}
Background : Leukemia is a type of non-transmitted disease that cause death with a large number of cases, especially in children. Leukemia is the most common childhood cancer. Acute Lymphoblastic Leukemia (ALL) is approximately 75\% of all cases. One of the main consequences of leukemia is inability of the immune system defending the body from the invasion of foreign objects. As a result of infection or bleeding is the most common cause of death in patient with leukemia. Diarrhea is one of the infections that can be found in children with Acute Lymphoblastic Leukemia. Diarrhea in children with Acute Lymphoblastic Leukemia can occur either from the disease itself or due to chemotherapy. The purpose of this study is to describe the incidence of diarrhea in children with acute lymphoblastic leukemia in Prof. R. D. Kandou Hospital Manado year period 2011-2015.

Methods : This study is a descriptive retrospective, with cross sectional approach by collecting data medical records of pediatric patient with ALL in RSUP Prof. Dr. R. D. Kandou Manado then describe the incidence of diarrhea. Samples were 60.

Results : The result obtained 60 patients who met the inclusion criteria, and 17 patients had diarrhea. Diarrhea in children with ALL is more common in induction phase, and the duration of diarrhea more to less than 7 days (acute diarrhea).

Conclusion : From this result, it can be concluded that the incidence of diarrhea in children with Acute Lymphoblastic Leukemia in Prof. DR. R. D. Kandou Hospital Manado year period 2011-2015 is low enough.
\end{abstract}

Keywords : Acute Lymphoblastic Leukemia (ALL), Diarrhea, Child

\begin{abstract}
ABSTRAK
Latar Belakang : Leukemia merupakan jenis penyakit tidak menular yang menyebabkan kematian dengan jumlah kasus yang tidak sedikit khususnya pada anak-anak. Leukemia adalah kanker anak yang paling sering. Leukemia Limfoblastik Akut (LLA) berjumlah kirakira 75\% dari semua kasus. Salah satu konsekuensi utama dari Leukemia adalah ketidakmampuan sistem imum mempertahankan tubuh dari invasi benda asing. Akibatnya infeksi atau perdarahan hebat adalah penyebab tersering kematian pada pasien leukemia. Diare merupakan salah satu infeksi yang dapat dijumpai pada anak dengan Leukemia Limfoblastik Akut. Diare pada anak dengan Leukemia Limfoblastik Akut dapat terjadi baik akibat dari Leukemia Limfoblastik Akut itu sendiri maupun akibat dari kemoterapi yang diberikan.
\end{abstract}


saluran cerna, infeksi dan hemoragi yang dapat berakibat fatal. ${ }^{6,7}$

Penelitian ini akan dilakukan pada anak dengan Leukemia Limfoblastik Akut, berdasarkan pertimbangan bahwa anak dengan Leukemia Limfoblastik Akut dapat terkena berbagai macam infeksi. Pada penelitian ini dilakukan hanya pada anak dengan Leukemia Limfoblastik Akut yang terkena diare untuk membatasi jangkauan penelitian.

\section{METODE PENELITIAN}

Penelitian ini bersifat retrospektif deskriptif, dengan pendekatan potong lintang dengan cara mengumpulkan rekam medik pasien anak dengan LLA, kemudian mendeskripsikan kejadian diare. Penelitian dilakukan di Pusat Pengobatan Kanker Ruang Estella Bagian Ilmu Kesehatan Anak RSUP Prof. Dr. R. D. Kandou pada bulan Oktober - Desember 2015. Populasi penelitian adalah seluruh pasien anak yang menderita Leukemia Limfoblastik Akut di RSU Prof. Dr. R. D. Kandou periode 2011-2015. Sampel penelitian adalah pasien anak dengan Leukemia Limfoblastik Akut yang mengalami diare di Ruang Estella Bagian Ilmu Kesehatan Anak RSU Prof. Dr. R. D. Kandou periode tahun 2011-2015.

\section{HASIL PENELITIAN}

Berdasarkan hasil penelitian yang dilakukan di Pusat Pengobatan Kanker Ruang Estella, dalam kurun waktu 5 tahun (2011-2015) terdapat 60 pasien dengan diagnosis LLA yang memenuhi kriteria inklusif peneliti.

Tabel 1. Distribusi jumlah karakteristik sampel berdasarkan usia

\begin{tabular}{lll}
\hline Usia & Jumlah (n) & $\begin{array}{l}\text { Persentase } \\
\text { (\%) }\end{array}$ \\
\hline$<1$ tahun & 0 & 0 \\
1-5 tahun & 36 & 60 \\
6-10 tahun & 13 & 21.7 \\
$>10$ tahun & 11 & 18.3 \\
\hline Jumlah & 60 & 100 \\
\hline
\end{tabular}

Dari tabel diatas terlihat bahwa kelompok terbesar responden terdapat pada usia 1-5 tahun, yaitu sebanyak $60 \%$ diikuti usia 6-10 tahun sebanyak 21,7\% dan terendah pada usia $>10$ tahun yaitu sebanyak $18,3 \%$.

Tabel 2. Distribusi jumlah karakteristik sampel berdasarkan jenis kelamin

\begin{tabular}{lll}
\hline $\begin{array}{l}\text { Jenis } \\
\text { Kelamin }\end{array}$ & $\begin{array}{l}\text { Jumlah } \\
\text { (n) }\end{array}$ & $\begin{array}{l}\text { Persentase } \\
\text { \% }\end{array}$ \\
\hline Laki-laki & 32 & 53.3 \\
Perempuan & 28 & 46.7 \\
\hline Jumlah & 60 & 100 \\
\hline
\end{tabular}

Dari tabel diatas terlihat bahwa sampel dengan jenis kelamin laki-laki dengan persentase 53,3\% lebih banyak dibandingkan sampel dengan jenis kelamin perempuan dengan persentase 46,7.

Tabel 3. Distribusi jumlah karakteristik sampel berdasarkan resiko LLA

\begin{tabular}{lll}
$\begin{array}{l}\text { Resiko } \\
\text { LLA }\end{array}$ & Jumlah (n) & Persentase \% \\
\hline $\begin{array}{l}\text { Standar } \\
\text { Risk LLA }\end{array}$ & 33 & 55 \\
\hline $\begin{array}{l}\text { High Risk } \\
\text { LLA }\end{array}$ & 27 & 45 \\
\hline Jumlah & 60 & 100 \\
\hline
\end{tabular}

Dari tabel diatas terlihat bahwa jumlah sampel dengan Standar Risk LLA dengan persentase $55 \%$ lebih banyak dibandingkan sampel dengan High Risk LLA dengan persentase $45 \%$.

Tabel 4. Distribusi jumlah karakteristik sampel berdasarkan kejadian diare.

\begin{tabular}{lll}
\hline $\begin{array}{l}\text { Kejadian } \\
\text { Diare }\end{array}$ & $\begin{array}{l}\text { Jumlah } \\
\text { (n) }\end{array}$ & $\begin{array}{l}\text { Persentase } \\
\text { \% }\end{array}$ \\
\hline Diare & 17 & 28.3 \\
Tidak Diare & 43 & 71.7 \\
\hline Jumlah & 60 & 100 \\
\hline
\end{tabular}


Dari tabel diatas terlihat bahwa jumlah sampel dengan diare dengan persentase $28,3 \%$ lebih sedikit dibandingkan dengan frekuensi sampel dengan tidak diare dengan persentase $71,7 \%$.

Tabel 5. Distribusi jumlah anak terdiagnosis LLA dengan diare berdasarkan kemoterapi

\begin{tabular}{lll}
\hline $\begin{array}{l}\text { Fase } \\
\text { Kemoterapi }\end{array}$ & $\begin{array}{l}\text { Jumlah } \\
(\mathbf{n})\end{array}$ & $\begin{array}{l}\text { Persentase } \\
(\%)\end{array}$ \\
\hline Fase Induksi & 11 & 64.8 \\
\hline $\begin{array}{l}\text { Fase } \\
\text { Konsolidasi }\end{array}$ & 3 & 17.6 \\
\hline $\begin{array}{l}\text { Fase } \\
\text { Reinduksi }\end{array}$ & 0 & 0 \\
\hline $\begin{array}{l}\text { Fase } \\
\text { Maintanance }\end{array}$ & 3 & 17.6 \\
\hline Jumlah & 17 & 100 \\
\hline
\end{tabular}

Dari tabel diatas terlihat bahwa jumlah anak terdiagnosis LLA dengan diare terjadi lebih banyak pada fase induksi pengobatan kemoterapi dengan persentase $64,8 \%$, diikuti fase konsolidasi dengan persentase $17,6 \%$ dan fase maintanance dengan persentase $17,6 \%$, sedangkan pada fase reinduksi tidak ditemukan adanya diare pada anak terdiagnosis LLA.

Tabel 6. Distribusi jumlah lamanya diare pada anak terdiagnosis LLA

\begin{tabular}{lll}
\hline $\begin{array}{l}\text { Lama } \\
\text { Diare }\end{array}$ & Jumlah (n) & $\begin{array}{l}\text { Persentase } \\
(\%)\end{array}$ \\
\hline$<$ 7 hari & 11 & 64.7 \\
7-14 hari & 5 & 29.4 \\
$>$ 14 hari & 1 & 5.9 \\
\hline Jumlah & 17 & 100 \\
\hline
\end{tabular}

Dari tabel diatas terlihat bahwa lamanya kejadian diare pada anak terdiagnosis LLA terjadi lebih banyak $<7$ hari dengan persentase $64,7 \%$, diikuti lama diare 7-14 hari dengan persentase 29,4\% dan lama diare $>14$ hari dengan persentase $5,9 \%$.

Tabel 7. Distribusi karakteristik status gizi anak terdiagnosis LLA dengan diare

\begin{tabular}{lll}
\hline Status Gizi & Jumlah (n) & $\begin{array}{l}\text { Persentase } \\
(\mathbf{\%})\end{array}$ \\
\hline Gizi Lebih & 1 & 5.9 \\
\hline Gizi Baik & 13 & 76.5 \\
\hline $\begin{array}{l}\text { Gizi } \\
\text { Kurang }\end{array}$ & 2 & 11.7 \\
\hline Gizi Buruk & 1 & 5.9 \\
\hline Jumlah & 17 & 100 \\
\hline
\end{tabular}

Dari tabel diatas terlihat bahwa jumlah anak terdiagnosis LLA dengan diare lebih banyak berada pada status gizi baik yaitu dengan persentase 76,5\%, sedangkan persentase status gizi kurang yaitu $11,7 \%$, status gizi lebih 5,9\% dan status gizi buruk 5,9\%.

\section{BAHASAN}

Leukemia limfoblastik akut merupakan keganasan tersering pada anak, berjumlah kira-kira 75\% dari semua kasus leukemia dan kira-kira seperempat dari seluruh keganasan anak. Di Indonesia diperkirakan terdapat 2000-3200 kasus baru jenis LLA tiap tahunnya, sedangkan pada penelitian ini yang dilakukan di Pusat Pengobatan Kanker Ruang Estella Bagian Ilmu Kesehatan Anak RSU Prof. Dr. R. D. Kandou Manado terdapat 60 orang anak yang didiagnosis LLA dan 17 orang anak yang didiagnosis LLA dengan diare selama kurun waktu tahun 2011-2015.

Berdasarkan hasil penelitian didapatkan bahwa rata-rata usia anak yang mengalami LLA dalam penelitian ini adalah usia 1-5 tahun, dengan usia termuda yaitu 1 tahun dan usia tertua yaitu 13 tahun. Yunita BP dalam penelitiannya yang dilakukan di RSUP Prof. Dr. R. D. Kandou menyebutkan bahwa rata-rata usia anak yang mengalami LLA adalah 1-10 tahun. ${ }^{8}$ Dalam literatur juga disebutkan bahwa leukemia adalah kanker yang paling sering mencapai 33\% dari keganasan 
pediatrik, dengan LLA berjumlah 75\% dari semua kasus keganasan, dimana insidens tertinggi LLA yaitu pada usia 4 tahun. ${ }^{1,3}$ Hidayat $\mathrm{R}$ dkk, dalam penelitian yang dilakukan di Divisi HematologiOnkologi Departemen IKA FKUI/RSCM menyebutkan bahwa rata-rata anak yang mengalami LLA berada pada kelompok usia $<5$ tahun dengan median usia subjek adalah 4 tahun 11 bulan (1 tahun 9 bulan17 tahun 1 bulan). Begitu juga dengan penelitian yang dilakukan oleh Ariawati dkk menyebutkan bahwa rata-rata anak yang mengalami LLA berada pada kelompok usia 1-10 tahun.,

Hasil penelitian karakteristik LLA berdasarkan jenis kelamin didapatkan bahwa anak laki-laki yang menderita LLA lebih banyak yaitu 53,3\%, dibandingkan dengan anak perempuan yaitu 46,7\%. Penelitian sebelumnya yang dilakukan oleh Paarang YB didapatkan bahwa anak laki-laki yang mederita LLA lebih banyak yaitu 52,2\% dibandingkan dengan anak perempuan yaitu $47,8 \% .^{8}$ Dalam literatur juga disebutkan bahwa LLA terjadi sedikit lebih sering pada anak laki-laki dibandingkan anak perempuan. Seperti penelitian yang telah dilakukan sebelumnya oleh Hidayat R dkk di RSCM mendapatkan bahwa anak laki-laki lebih banyak terserang LLA daripada anak perempuan dengan rasio $2: 1{ }^{11}$

Hasil penelitian karakteristik LLA berdasarkan resiko LLA didapatkan bahwa resiko standar (standard risk) LLA lebih banyak dibandingkan resiko tinggi (high risk) LLA dengan persentase resiko standar (standard risk) LLA sebesar 55\%, dan persentase resiko tinggi (high risk) LLA sebesar $45 \%$.

Definisi dari high risk itu sendiri adalah keadaan dimana saat dignosis anak berumur $<1$ tahun atau $>10$ tahun, hitung leukosit > 50.000/ $\mathrm{mm}^{3}$, massa mediastinum $>2 / 3$ diameter rongga thoraks, adanya sel leukemik $>5 \mu$ m pada cairan serebrospinal. Sedangkan standar risk adalah keadaan dimana saat diagnosis anak tidak memiliki tanda-tanda yang sudah disebutkan dalam definisi high risk. Dalam penelitian yang dilakukan oleh Permatasari E dkk di RSCM didapatkan 64,3\% kelompok resiko standar (standard risk) LLA dan 35,7\% kelompok resiko tinggi (high risk) LLA. ${ }^{12}$

Berdasarkan hasil penelitian
didapatkan bahwa dari 60 anak
terdiagnosis LLA, 17 anak mengalami diare yaitu dengan persentase 28,3\%, sedangkan 43 anak tidak mengalami diare yaitu dengan persentase $71,7 \%$. Dapat dilihat bahwa anak terdiagnosis LLA dengan diare lebih sedikit dibandingkan dengan anak terdiagnosis LLA yang tidak mengalami diare.

Sesuai dengan literatur yang menjelaskan bahwa salah satu konsekuensi utama dari LLA adalah ketidakmampuan sistem imun mempertahankan tubuh dari invasi benda asing, sehingga mudah mengalami infeksi. Infeksi adalah komplikasi kemoterapi yang paling sering, dan merupakan penyebab kedua dari seluruh kematian pada anak ALL. Infeksi salah satunya adalah diare. Diare pada anak dengan LLA dapat disebabkan oleh invasi bakteri/virus baik setelah terjadi imunosupresi, maupun akibat dari kemoterapi yang memiliki sifat toksik dan mengganggu sel pada jaringan berproliferasi tinggi yaitu sistem hemopoietik dan terutama sistem gastrointestinal. ${ }^{4,13,14}$

Dalam penelitian yang dilakukan oleh Hidayat R dkk di RSCM, didapatkan bahwa dari 30 orang subjek penelitian terdapat 6 orang yang mengalami diare dengan persentase yaitu 20\%. Hasilnya kurang lebih mirip dengan hasil penelitian yang dilakukan oleh peneliti di RSUP Prof. Dr. R. D. Kandou Manado. ${ }^{10}$

Berdasarkan hasil penelitian didapatkan bahwa menurut fase kemoterapi LLA sesuai protokol LLA, ditemukan 11 anak mengalami diare pada fase induksi kemoterapi dengan persentase 64,8\%, 3 anak mengalami diare pada fase konsolidasi dengan persentase 17,6\%, 3 anak mengalami diare pada fase 
maintanance dengan persentase $17,6 \%$, sedangkan pada fase reinduksi tidak ditemukan adanya diare pada anak terdiagnosis LLA. Dari hasil tersebut dapat dilihat bahwa kejadian diare pada anak terdiagnosis LLA lebih banyak terjadi pada fase induksi kemoterapi.

Dalam penelitian yang dilakukan oleh Ariawati K dkk, disebutkan bahwa keluhan mual, muntah, stomatitis, diare, terbanyak terjadi pada minggu kelima fase induksi kemoterapi yaitu setelah pemberian metotreksat (MTX) dosis 1 gram yang pertama. Dalam penelitiannya didapatkan 21 orang anak dengan LLA mengalami diare sejak minggu pertama hingga minggu ke tujuh fase induksi kemoterapi. $^{9}$

Berdasarkan hasil penelitian yang telah dilakukan, didapatkan bahwa ratarata lamanya diare pada anak terdiagnosis LLA adalah $<7$ hari yaitu berjumlah 11 orang anak dengan persentase $64,7 \%$, sedangkan anak terdiagnosis LLA dengan diare $>14$ hari hanya ditemukan pada 1 orang anak. Dari hasil tersebut dapat dilihat bahwa anak terdiagnosis LLA lebih banyak mengalami diare akut dari pada diare kronis.

Dalam literatur telah dijelaskan bahwa diare akut adalah buang air besar pada bayi atau anak lebih dari 3 kali perhari, disertai perubahan konsistensi tinja menjadi cair dengan atau tanpa lendir dan darah yang berlangsung $<7$ hari. Sedangkan diare kronis adalah buang air besar lebih dari 3 kali perhari disertai perubahan konsistensi tinja menjadi cair dengan atau tanpa lendir dan darah yang berlangsung $>14$ hari dengan dasar etiologi non-infeksi, serta diare persisten yang mempunyai dasar etiologi infeksi. ${ }^{15}$

Berdasarkan hasil penelitian didapatkan bahwa anak terdiagnosis LLA dengan diare rata-rata memiliki status gizi baik yaitu berjumlah 13 orang anak dengan persentase $76,5 \%$. Begitu pula dengan penelitian yang dilakukan oleh Conny $\mathrm{T}$ dkk di RS Pantai Indah Kapuk yang menemukan bahwa rata-rata anak dengan LLA memiliki status gizi baik, dan tidak ada obesitas. ${ }^{24}$

Status gizi anak terdiagnosis LLA dengan diare diukur menggunakan CDC 2000 untuk anak lebih dari 5 tahun, dengan ditentukan oleh berat badan dan korelasinya dengan tinggi badan. Sedangkan untuk status gizi anak terdiagnosis LLA dengan diare dan berumur dibawah 5 tahun maka dalam pengukurannya digunakan z-score WHO 2006.

Dalam penelitian sebelumnya yang dilakukan oleh Ariawati K dkk, didapatkan bahwa rata-rata anak dengan LLA memiliki status gizi baik kemudian disusul oleh anak dengan LLA yang memiliki status gizi cukup. Sama dengan penelitian yang dilakukan oleh Hidayat $\mathrm{R}$ dkk, didapatkan bahwa rata-rata anak dengan LLA memiliki status gizi baik yaitu sebanyak 16 orang dari 30 subjek penelitian dengan persentase sebesar 54\%, kemudian diikuti oleh status gizi kurang yaitu sebanyak 12 orang anak dari 30 subjek penelitian dengan persentase sebesar $40 \%{ }^{9,10}$

\section{SIMPULAN DAN SARAN}

Angka kejadian diare pada anak dengan LLA di RSUP Prof. Dr. R. D. Kandou Manado cukup rendah. Kejadian diare pada anak dengan LLA terjadi lebih banyak pada fase induksi pengobatan kemoterapi. Berdasarkan lamanya diare didapatkan bahwa kejadian diare pada anak dengan LLA lebih banyak terjadi pada $<7$ hari. Sedangkan status gizi anak dengan LLA dan mengalami diare lebih banyak berada pada status gizi baik

Hasil penelitian mengenai kejadian diare pada anak dengan LLA yang dilakukan di Pusat Pengobatan Kanker Ruang Estella RSUP Prof. Dr. R. D. Kandou pada tahun 2011-2015 didapatkan kejadian diare yang rendah, namun demikian dibutuhkan pencegahan infeksi dalam hal ini diare, agar tidak terjadi peningkatan angka kejadian diare pada anak dengan LLA dan untuk memperbaiki 
kualitas hidup dari anak-anak yang terdiagnosis LLA.

Untuk peneliti selanjutnya disarankan untuk meneliti lebih lanjut lagi mengenai penggunaan obat kemoterapi yang dapat menyebabkan diare pada anak dengan LLA. Disarankan juga untuk menganalisa kejadian diare pada anak dengan Leukemia Limfoblastik Akut.

\section{DAFTAR PUSTAKA}

1. Crist, WM. Pui, CH. Dalam: Behrman, Kliegman, Arvin, editor. Nelson Ilmu Kesehatan Anak. Edisi ke-15. Vol-3. Jakarta: Penerbit Buku Kedokteran EGC; 2000. h: 1772-80

2. Baldy, CM. Dalam: Sylvia A. Price, Lorraine M. Wilson, editor. Patofisiologi Konsep Klinis ProsesProses Penyakit. Edisi ke-6. Vol-1. Jakarta; Penerbit Buku Kedokteran EGC, 2012. h: 271-81

3. Simanjorang, C. Kodim, N. Tehuteru, E. Perbedaan Kesintasan 5 Tahun Pasien Leukemia Limfoblastik Akut dan Leukemia Mieloblastik Akut pada Anak di Rumah Sakit Kanker "Dharmais", Jakarta, 1997-2008. Indonesian Journal of Cancer. 2013; 7:15-21.

4. Sherwood, L. Fisiologi Manusia. Edisi ke-2. Jakarta; Penerbit Buku Kedokteran EGC, 2001. h: 355-56

5. Guyton, A. Hall, JE. Pertahanan Tubuh Terhadap Infeksi: Leukosit, Granulosit, Sistem MonositMakrofag, dan Inflamasi. Dalam: Buku Ajar Fisiologi Kedokteran Edisi ke-11. Jakarta: Penerbit Buku Kedokteran EGC.2007. h: 450-9

6. Nafraldi, Gan, S. Antikanker. Dalam: Farmakologi dan Terapi. Jakarta; Bagian Farmakologi FK UI; 2008. h: 732-56

7. Marcellus, SK. Daldiyono. Dalam: Sudoyo, A. Setiyohadi, B. Alwi, I. Simadibrata, M. Setiati, S, editors. Buku Ajar Ilmu Penyakit Dalam.
Edisi ke-4. Jakarta: PDSPDI; 2007. h: 408-13

8. Paarang, YB. Mantik, MFJ. Gunawan, S. Hubungan Antara Ratio Netrofil Limfosit dengan Klasifikasi pada Leukemia Limfoblastik Akut. Jurnal e-Clinic (eCl). 2015; 3:157-60.

9. Ariawati, K. Windiastuti, E. Gatot, D. Toksisitas Kemoterapi Leukemia Limfoblastik Akut pada Fase Induksi dan Profilaksis Susunan Saraf Pusat dengan Metotreksat 1 gram. Sari Pediatri. 2007; 9:252-8.

10. Hidayat, R. Gatot, D. Djer, MM. Validasi Sistem Skoring Rondinelli untuk Mendeteksi Komplikasi Infeksi Berat pada Pasien Leukemia Limfoblastik Akut L1 dengan Demam Neutropenia Selama Kemoterapi Fase Induksi. Sari Pediatri. 2014; 15:325-51.

11. Hidayat, R. Gatot, D. Djer, MM. Validasi Sistem Skoring Rondinelli untuk Mendeteksi Komplikasi Infeksi Berat pada Pasien Leukemia Limfoblastik Akut L1 dengan Demam Neutropenia Selama Kemoterapi Fase Induksi. Sari Pediatri. 2014; 15:325-51.

12. Permatasari E. Windiastuti E, Satarri HI. Survival and Prognostic Factors of Childhood Acute Lymphoblastic Leukemia. Paediatrica Indonesiana. 2009; 49:365-71.

13. Kumar, Cotran, Robbins. Gangguan Sel Darah Putih. Dalam: Buku Ajar Patologi. Edisi ke-7. Vol-2. Jakarta; Penerbit Buku Kedokteran EGC. 2007. h: 475-76

14. Mia, Ugrasena IDG, Permono B. Pengelolaan Medic Anak dengan Leukemia dan Kemungkinan Perawatan di RS Kabupaten. Divisi Hematologi-Onkologi BIKA. FK Unair RSU Dr. Soetomo Surabaya. 2006. 
15. Subagyo, B. Santoso, NB. Diare Akut. Dalam: Juffrie, M. Sunarto SSY, editor. Buku Ajar Gastrornterologi-Hepatologi. Edisi ke-1. Jakarta: IDAI. 2012. 